\title{
Between the Scylla and the Charybdis: Theological education in the 21st century in Africa
}

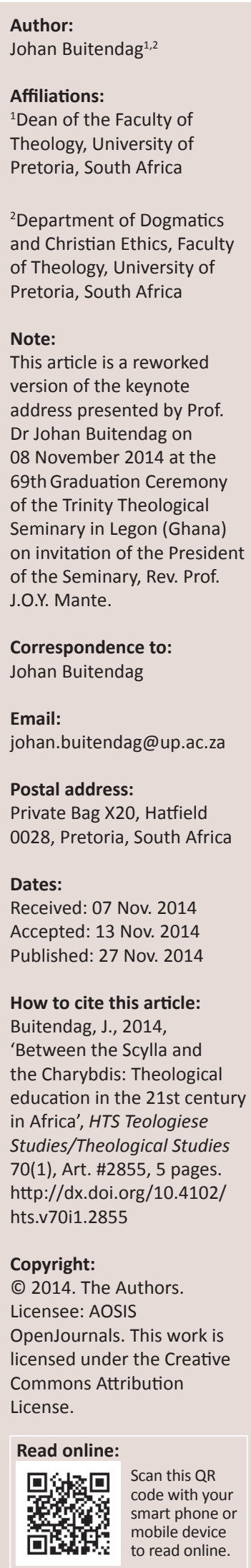

The article reflects on the challenges of theological education in the 21st century and in Africa. Reputation, impact, success and funding have become the driving forces of the modern university. However, we are living in the 21st century and in Africa with a subsequent frame of reference that is holistic and faith-based. The article therefore argues for a multi- and transdisciplinary approach towards the nature of a university and recognition of the unique contribution theological education can contribute. Due to the inherently cooperative nature of theological scholarship, theological education could be able to avoid the extremes of the Scylla and the Charybdis, that is, fideism and secularisation, and therefore be able to survive at an academic institution. Both sectarianism and scientism should be avoided. Theological education in Africa needed to travel the same difficult road of theological faculties in Europe in the previous century.

\section{The challenges facing theological education today}

South Africa with its apartheid past has for too long seen itself as a little Europe, a little England or a little Netherlands or Germany. For too long the relationship with our neighbouring and other countries on the continent has been either hostile or non-existent. Some of the early settlers in Africa even thought that they had brought civilisation to the Dark Continent! Fortunately this attitude has changed. It is replaced however nowadays by matters such as the exploitation of Africa's mineral wealth, the devastating effect of the First World's toxic waste being dumped in Africa, and the arrogant attitude that the wild areas of Africa are the playground for the hunting safaris of the world's millionaires.

Whether theological education is situated at a church seminary or at a state university, it has come under severe pressure. From the eight theological faculties at public universities in the previous century in South Africa, only four still exist today. The 21st century has brought about new challenges and so too the world powers' interest in the wealth and potential of Africa. It is as if there is a neo-colonisation of Africa taking place.

The subject-matter of academic theological education is here qualified by two aspects, namely Africa en the 21st century. This topic cannot, in my opinion, be deliberated responsibly without taking both the continent and the century into account.

The topic of this article, however, needs further clarification. Scylla and Charybdis were two mythical sea monsters noted by Homer in Books 12-14 of his Odyssey. They were regarded as sea hazards located close enough to each other that they posed a threat to passing sailors. Avoiding Charybdis meant passing too close to Scylla and of course, vice versa. Theological training has this double threat as well. On the one hand it can become what I would like to call a fideism and on the other hand, it could become a scientism. These extremes are like sectarianism versus secularism. While Europe has fallen victim to secularism, Africa could find herself on the verge of sectarianism when it encapsulates its theological training. Either you make too much of science or you make too much of ecclesial tradition.

My hypothesis is that there is a third option out of this impasse and this is, in the words of Alister McGrath (2004), a 'Scientific Theology'. It is scientific, but not scientistic; it is faith-based, but not fideistic. Corollary to this hypothesis is, as already has been indicated, the space and time coordinates that contextualise theological education. The human person is to be understood in terms of an eco-cultural environment which can neither be pure subjective nor pure objective. God is to be discerned in creation and revelation, as around, above, with in and even beyond us and not as Karl Barth asserted as 'perpendicularly from above'. Anselm immortalised this truth by stating, 'faith seeking understanding'. The human person entails mind and body, faith and reason. And this copula noun is the pivotal point of the balancing act and the crunch of this article. 
Theological education is an inclusive and lifelong learning process that is accountable to both ecclesial traditions and research communities. The term 'education' is consciously chosen instead of 'training' because education is not a process of filling a pail or bucket but rather that of 'lighting a fire' (ascribed to the poet William Butler Yeats). If the church does not identify itself with a specific theological education or if the scientific community is indifferent to its research, such a theological institution is doomed. It is my sincere conviction that theology is in her deepest sense an endeavour to understand reality and that theology not only can, but must collaborate with other sciences to this end. Theology can indeed contribute to come to grips with reality. Ecclesial and scientific accountability is a sine qua non for responsible theological education. And both these points, like in an ellipse, are integral to my argument.

\section{The development of Christian education at a university}

Where does the idea of a university come from? The answer to this question is a sort of double helix. It has a nonChristian as well as a clear Christian genesis. The very early Ionian Greek philosophers tried to find the one unchanging primordial thing (arche) already six centuries before Christ. Thales presupposed that different things are composed of a common denominator, namely water. All things were actually only manifestations of this basic element. Everything but water can perish. Water imparts eternal stability and causal orderliness to the many changing things in the cosmos.

Although other philosophers of the time followed in the footsteps of Thales in seeking one common unchangeable basic element, it happened to be Heraclitus who rejected the idea of any stable or unchanging element in all things by stating that one cannot step into the same river twice. The hallmark of reality is that all things are in a constant state of change or flux. Based on experience and sense observation, Heraclitus could state that fire although continually changing, is always constant. It might be understood to continually consume and ultimately yield the changing things we experience.

What is important about these early Greek philosophers is that they suppose a view of knowledge (epistemology) that ties reason to observation. Heraclitus went thus beyond Thales's position by arguing much more inductively in understanding reality. His notion of unity in diversity is a unified manifestation of eternal Reason. This reason is to be understood to be 'God'. Thales had contributed to the idea of scientific knowledge, but Heraclitus emphasised sense experience and mitigated the role of speculative theory in the domain of science. Much emphasis was thus put on observational corroboration.

The first academy in the West was the school of Plato, established in about $387 \mathrm{BCE}$ in Athens. It was more than only the first centre of higher learning in Western culture. Plato established a general rationale for academies to follow in their pursuit of truth. What is important about the philosophy of Plato is his presupposition of a tripartite view of reality, as is excellently described in his cave metaphor. Both ontological and epistemological contours are drawn from this metaphor: a person in the back of the cave can only apprehend shadows; a person by the fire sees tangible figures; and a person in the sunlight as a state of mind of knowledge and grasps ideas (Trundle 1994:105). Education is therefore required to lead persons out of the darkness of ignorance into the light of knowledge. Since knowledge would be resisted, the state has to marshal the process and even enforce education.

Aristotle left the Academy around the death of Plato due to many reasons. With the backing of Alexander the Great, Aristotle established a flourishing research school in the Lyceum. In the extension of Heraclitus's inductive preference, he developed a view that reason is responsive to empirical investigations. Aristotle grew up in a family of doctors and biologists and most probably this led him to have a bottom-up approach in understanding reality; exactly the opposite of what Plato inferred. The intellect passes from the individual to universals. For Aristotle ontology is existing categories embodied by perceptible individuals. Truth is what mirrors reality and hence the 'correspondence theory of truth' was born, the rationale for many Western universities today (Rorty 1980).

With the collapse of the Roman Empire, the educational system of the West fell apart. This was replaced by the monastic schools which happened to be the basis for the later universities like Bologna, Paris and Oxford established during the 13th century. The Medieval curriculum prepared the student to read, write and think Latin, primarily in order to access the Holy Scriptures. This base-curriculum was called the Trivium pertaining to grammar, rhetoric and dialectic. Beyond the trivium lay the Quadrivium - music, arithmetic, geometry and astronomy - which completed the so-called liberal arts, or artes liberales.

Christian education however, was always driven by a different Leitmotiv. Observation should lead to contemplation. The acknowledgement of the supreme value of reflection has been linked to the acknowledgement that reality is more than mere observation. Discernment is the supreme goal of humankind. To perceive God is rather what all is about (Alston 1991). The monks had to be educated to fulfil their vocations and fundamental to that was they had to come to know God. Contemplation was therefore the most important end of the sequence lectio, meditatio, oratio, contemplatio (reading, meditation, prayer and contemplation). This reading, thinking and pondering ultimately led the monk to contemplation: to looking at God, being aware of God's presence (Louth 2004:70). Human intelligence is therefore to be understood in a double way: on the basic level is doing things and the other is beholding and contemplating.

John Henry Newman (1982) published a book in 1852 with the romantic title, The idea of a university. It is even said that 
modern thinking on university education is only a series of footnotes to Newman's lectures and essays (Pelikan 1992:6). For Newman a university is not an institution, but an idea. Knowledge is there for its own end and the ideal of universal knowledge is the driving force (Newman 1982:74-92). What is integral to Newman's idea of a university is that theology is a branch of this universal knowledge, because all knowledge forms one whole or 'circle' from which the various branches of learning stem. Religious truth is not only an aspect, but a condition of general knowledge. Therefore it is so important of pushing things up to their first principles. This is according to Newman a sine qua non for the idea of a university. Very important to the First Principles, is that it is a process and not really first of all, 'a priori', but an 'ex post facto'; what is 'a priori' is not a principle, but the practise and the structure (Pelikan 1992:28). This exposition is clearly dished on the table laid by Aristotle.

The Enlightenment with the subsequent secularisation shattered this idea of a university. Karl Marx, in his famous comment from the Theses on Feuerbach, wrote: 'The philosophers have only interpreted the world in different ways; the point is to change it.' Charles Taylor (2007:7) for example, describes the rise of the secular in the Western world as a 'move from a society where belief in God is unchallenged and indeed unproblematic, to one in which it is understood to be one option among others, and frequently not the easiest to embrace.' Richard Rorty also claims that religion still needs to be privatised. For those outside the relevant religious community religion is a mere 'conversationstopper' (MacDonald 2010:993).

\section{The driving forces of 20th century universities}

Like Pelikan (1992:15) using the Four Horseman of the Apocalypse as a metaphor, I would like to apply this metaphor to my interpretation of the effect of secularisation on the idea of a university. The power to kill could happen by sword, famine, pestilence and the wild beasts of the earth.

Allow me to modify these in terms of what, in my opinion, have become the driving forces of modern universities. What is important is that an approach is being followed where only that type of research that leads to problem-solving is of any importance. A type of utilitarianism is therefore born in the process:

\section{Pragmatic research (war)}

The life of the university throughout the 20th century was dominated by two world wars and threats of potential ones. Whether it was manufacturing weapons, designing of aircraft or submarines or even the building of roads and bridges, this was a means to a different end. It is widely known that world powers need wars to keep their economy going.

\section{Economic demands (hunger)}

The world has to be fed. The limited resources force scientists to develop new and better nutritional resources. Genetic modification, hormone stimulation, artificial substitutes are more and more accepted as the obvious solution to feed the billions of people on planet earth.

\section{Health science (pestilence)}

The whole history of humankind testifies of massive tragedies caused by pestilences. Despite the tragedies of modern pandemics like HIV and Aids and lately the Ebola virus, the malaria mosquito is still the cause of the most deaths in the world. Research on these viruses is forcing scientists to find cures and preventative medicine.

\section{Ecological crisis (nature)}

Since the Club of Rome made us aware of the limits to growth in 1972 and the subsequent threatening ecological crises, much research was done into all areas of the threats of industrialisation, depleting of natural and nutritional resources, pollution and an overpopulated world.

Thus the classical idea of the university has been replaced by a new phenomenon. Against the above backdrop and the fact that the world has become merely a village, the following have emerged as driving forces of universities today: reputation, impact, success and funding.

Andrew Louth is very blunt in saying that this is undermining the idea of the university as a place of intellectual virtue and contemplation and universities are changing into pure educational businesses. Academics must deliver and that product must be saleable, or at least subject to quality control:

This is the rationale of quality assurance assessments and research assessment exercises: we produce education, which is consumed by students, and research, consumed by our peers and these things can be quantified and assessed. (Louth 2004:75)

Perhaps it is appropriate to be reminded of the old cliche that says that not everything that counts can be counted!

In order to measure, there has of course to becertain quantitative indicators and subsequently different instruments. The ranking number and world position are today the main focus of the mission of most international universities. This was initiated by the Chinese government to measure progression and to catch upon scientific research. The first ranking was compiled by Shanghai Jiao tong University in 2003. The four main instruments today are the Academic Ranking of World Universities (ARWU), the Times Higher Education World University Ranking (THE), the QS World University Ranking (QS-WUR) and the Leiden Ranking. In most of these indices, much emphasis is placed on impact research in natural sciences as reflected by highly cited journals like Nature and Science. 
We are living in the 21st century with a subsequent frame of reference that is postmodern. The prefix in the noun 'university' could therefore be replaced by the word 'multi', that is multiversity. For theological education at a secular university this is a positive trend. Social good could not be reduced to purely economic good and epistemology could not be understood in the singular anymore. There are multiple perspectives and all understanding could contribute to comprehend reality. Not one science alone is capable to provide a whole picture of reality. Cooperation and consultation should be $360^{\circ}$ in the round. All these different vantage points of cause have to be accountable to certain methodological verification. Scholarly contribution should be recognised by peers and appreciated in the specific field of research. A scientific approach is therefore always critical and aware of other relevant disciplinary work. And this is the challenge for theological education at the academy, whether it is at a university or a seminary.

Proper theology has to be methodologically accountable if one wants to pass safely through the Scylla and Charybdis. With this I mean in the thoughts of McGrath that a scientific theology has to be an 'integrated system', based on an 'iterative method', which needs 'to be made explicit and incorporated into any discussion of theological method' (McGrath 2006:195). To this, he adds inter alia the importance of 'the identification of the scientific and theological consequences of the postmodern deconstruction of nature' (McGrath 2004:11). In my words then, Systematic Theology is the endeavour to understanding reality.

It is clear that I do not want to see theological education in isolation tending towards sectarianism. An insular approach should be avoided and theology should be public. It should be neither polemic, nor indifferent to natural sciences (note the absence of the deliberate article) and should be in critical dialogue with different sciences, interacting with other disciplines on its own terms.

Theology does not have to abandon its understanding of reality, based on the Christian doctrine of creation. In the conclusion of this article I will come back to this notion of qualifying theology's enterprise as Christian. I do want to emphasise that this is the unique proposition that Christian theology can offer and should never barter it. Wherever this happens, we are excluded from all public debate with regards to a unique understanding of reality and subsequently, from a multiversity too.

The report on the Quality Assurance of Netherlands Universities (QANU 2012) stated the following important perspective on the place of theology at a university:

It is important for theology to be present in secular universities. It has a very positive role to play in providing reflective enquiry into fundamental questions of human nature and existence, and in exploring the approaches to those questions with in one or more major and historically crucial religious traditions. Theology has therefore to be conserved as an autonomous discipline with its own theory-building and methodology, independently of the external approach of religion by religious studies and of its more instrumental use for ministerial training, and also irrespective of the commitment to church policies. (p. 9)

The moment when theology were to give up its identity as a legitimate, coherent intellectual discipline, it definitely will end up in secularism. Theology should opt for a third option between the top-down approach of Thales or Plato and the bottom-up approach of Heraclitus and Aristotle. An abductive method which is something of a hybrid of the two and which oscillates between these two vantage points could be a more commendable route to follow. McGrath is therefore correct when he stresses the importance of iteration as an aspect of methodology. John Henry Newman correctly contended that being able to see something 'from all sides' or 'in the round' cannot, by definition, be a specialism in its own right (Collini 2012:loc. 987). A posteriori one is to get to the arche of all things.

\section{Church, University and Theological education}

The starting point cannot be nature. If that would be the case, we turn Anselm's dictum in the inverse and incorrectly claim that because we understand, we believe. Faith seeking understanding is the correct order. And faith is always embedded in tradition, where tradition is to include various levels of revelation. Theology, and specifically Systematic Theology, begins with the actuality of the church as embodied tradition (McGrath 2006:195) and in dialogue with others, develops an understanding of reality, subject of course to ongoing revision and reflection. One could see it as secondorder and third-order rational discourses as Gavin Flood suggests (MacDonald 2010:996). The former is the critical reflection of a given religious tradition on itself and the latter on forms of secular reasoning and methodologies developed by Western academy.

The church is important in the formation of scientific theology. This identification safeguards theology from becoming secularistic and to fare carefully through the Scylla and Charybdis. We all know that the word 'theology' derives from the two Greek words, theos and logos meaning 'God' and 'word'. But the challenge is to use the correct preposition in combining the two words. Is it the talk of God or perhaps the talk about God? My plea is that it is both! The church guides us to hear the Word of God and the academia guides us to engage with talk about God. Theology is the revelation of God grasped in faith (Karl Rahner) and this demands both a top-down and a bottom-up iteration approach.

This means that Christian education at the university has to be open to ecclesial partnerships and the church in turn, has to be receptive to scientific inquiry.

My premise is that theological scholarship is in fact an inherently cooperative enterprise. Academy and universities 
are organisations for the creation, maintenance and dissemination of intellectual enquiry. Collini (2012:loc. 3172) outs it as follows: 'Universities provide a home for attempts to extend and deepen human understanding in ways which are, simultaneously, disciplined and illimitable'. What it tries to achieve is not knowledge $=$ skills + information, but understanding $=$ experience + reflexion. In contemplation, the final end of intellectual enterprise, we find what is highest in human nature's fulfilment. And that highest is what is divine in human beings: human nature finds its fulfilment in transcending itself (Pannenberg 1970:1-13).

In conclusion, the distinction between 'theology' and 'religious studies' needs to be emphasised once more. If this distinction is to be abolished, theology dissolves in the Humanities and has to comply with all the demands of the various academic disciplines that study religious phenomena. Theology will lose its unique character and would exist only in the plural as one of many human enterprises. The notion of 'revelation' would be redundant and even be annoyed by scholars.

David Ford (1997:723) wonders how hospitable academic institutions would be to theology in future. I want to provide my own answer to this question as a sort of synopsis of the thrust of my argument. Hospitability at a university depends in my view, upon:

1. the scholarly contribution theology can make as an important perspective on understanding reality

2. the extent to which it can be methodologically accountable

3. the resilience it shows to immanent criticism

4. the fidelity it asserts to its subject-matter as science of God; the values it reflects and the social cohesion it inaugurates in society; and of course

5. the idea of a university.

Theology is the one discipline that can stand up against the nihilism of secularism. The extremes of fideism and secularisation could only be overcome by a theology that is both academically sound and ecclesially embedded. The fact that we are in the 21st century and in Africa, means that we do not have to invent the wheel a second time and that we need to go through the same trauma Europe went through with its history of secularisation the past century or two. Some African scholars are very convinced that Western theology has 'lost the plot' when it comes to authentically articulating the Christian faith as seen in the 'centre of gravity' that has shifted from the North to the South (Balcomb 2013:580).

The vision and mission of the Faculty of Theology at the University of Pretoria perhaps succeed in finding the gateway through the Scylla and Charybdis. It is written in moving and emotive, yet humble and inclusive language:

Vision: To be a faculty recognised for its creative engagement with life-giving theology and religious insight, of service to academia, church and community.

Mission: To achieve this, we commit ourselves to -

- Providing relevant theological and religious education;

- Nurturing transformative leaders;

- Quality research;

- Promoting justice, peace, the integrity of creation and a reconciling diversity; and

- Engaging people on the margins of society.

The spirit of Africa and the world view of the people of this great continent are so much more holistic and faith-based that I really believe that scientific theology will survive the dangerous route between the Scylla and the Charybdis.

\section{Acknowledgements Competing interests}

The author declares that he has no financial or personal relationship(s) that may have inappropriately influenced him in writing this article.

\section{References}

Alston, W.P., 1991, Perceiving God: The epistemology of religious experience, Cornel University Press, Ithaca, NY.

Balcomb, T., 2013, 'Theological education and the relevance of African worldviews: Shifting the paradigm', in I. A. Phiri \& D. Werner (eds.), Handbook of theological education in Africa, pp. 576-588, Regnum Books International, Dorpspruit.

Collini, S., 2012, What are universities for?, Penguin Books, London. (Kindle edn.).

Ford, D., 1997, 'Christian theology at the turn of the millennium', in D. Ford \& R. Muers (eds.), The modern theologians, pp. 720-728, Blackwell Publishing, Oxford.

Louth, A., 2004, 'Theology, contemplation and the university', Studies in Christian Ethics 17(1), 69-79. http://dx.doi.org/10.1177/095394680401700105

MacDonald, P.A., 2010, 'Studying Christian theology in the secular university', Journal of the American Academy of Religion 4(78), 991-1024. http://dx.doi.org/10.1093/ jaarel/Ifq053

McGrath, A.E., 2004, The science of God: An introduction to scientific theology, T\&T Clark, London. http://dx.doi.org/10.1002/9780470690918

McGrath, A.E., 2006, The order of things: Explorations in scientific theology, Blackwell Publishing, Oxford.

Newman, J.H., 1982, The idea of a university, University of Notre Dame Press, Notre Dame, IN.

Pannenberg, W., 1970, What is man? Contemporary anthropology in theological perspective, Fortress Press, Philadelphia, PA.

Pelikan, J., 1992, The idea of the university: A reexamination, Yale University, New Haven, CT.

Quality Assurance Netherlands Universities (QANU) Report, 2012, Research self evaluation of the Faculty of Theology (2005-2011), VU University, Amsterdam.

Rorty, R., 1980, Philosophy and the mirror of nature, Princeton University Press, Princeton, NJ.

Taylor, C., 2007, A secular age, Harvard University Press, Cambridge, MA.

Trundle, R.C., 1994, Ancient Greek philosophy: Its development and relevance to our time, Avebury, Aldershot. 